\title{
Impact of climate variability on rainwater savings: A case study for Sydney
}

\author{
M. Moniruzzaman and Monzur A. Imteaz \\ Department of Civil and Construction Engineering, Faculty of Science, Engineering and Technology \\ Swinburne University of Technology, Melbourne, VIC 3122, Australia \\ Email:mmoniruzzaman@swin.edu.au
}

\begin{abstract}
With the growing population and ever-increasing water demand water authorities of many highly populated cities are struggling to maintain potable water supply for the residents. Without effective measure(s) the situation is expected to get worse day by day. To reduce the potable water demand, several methods/systems were proposed; rainwater harvesting, greywater reuse, recycled (treated) water supply and using water efficient appliances. Among all the water harvesting and recycling systems, Rain Water Harvesting System (RWHS) is considered to be the most effective, reliable and safe if used for non-potable purposes. Rainwater tank is the most common form among all the rainwater harvesting systems. For many remote communities rainwater tank is essential as they have to buy expensive bottle water for daily consumptions. In some urban areas due to lack of resources authorities are unable to provide continuous water supply. Even among urban communities where efficient urban water supply exist, rainwater tank is increasingly being used for non-potable purposes (i.e. garden irrigation, toilet flushing, cloth washing etc.) to reduce potable water consumptions. RWHS comprises with a rainwater collection surface (eg. roof), water storage (eg. water tank), pumping system for distribution and other accessories (eg. first flush diverter, overflow). However, optimisation of this system both in water savings and reliability is a challenge. Various studies and methods of analyses have been used in this regard. Among methods of analysing RWHS, a daily water balance method is most feasible and reasonably accurate. However, most of the relevant past studies using daily data used continuous simulations of historical daily rainfall for a long period, which provides single averaged outcomes (i.e. water savings, reliability, overflow etc.). Through such analysis of averaged variables, rainwater tank users do not get an adequate insight of the expected realistic situation(s) in regards to variability of outcomes. With the impacts of climate change, such ranges of realistic outcomes are expected to be widening further. This paper presents analyses from a recently developed daily water balance model (eTank), which calculates rainwater tank outcomes under three different climatic conditions (i.e. dry, average and wet years). To investigate the climatic variability fifteen representative years (five for each dry, average and wet conditions) were selected from historical rainfall data collected from a coastal site (Sydney Observatory Hill) of an Australian major city, Sydney. Calculated expected annual rainwater savings were compared with the calculated water savings generated by widely used tool, 'Raintank Analyser', which uses historical daily rainfall data for many years and presents an average of all the calculated years' cumulative water savings. It is found that 'Raintank Analyser' calculated water savings closely match with the eTank calculated water savings in average year, which is reasonable and ascertains eTank's accuracy. However, significant climatic variations in water savings are expected for the particular location as calculated by eTank. Also, eTank calculated water savings were compared with the published results from another continuous simulation type water balance model, CSWBM for the same rainfall station for large roofs. Calculations were performed considering same conditions in regard to daily rainwater demand, roof area, losses and tank volume. It is found that CSWBM produced water savings significantly vary with the eTank calculated water savings; for smaller tank sizes CSWBM calculated water savings are even lower than the eTank calculated water savings in dry year, whereas for larger tank sizes CSWBM calculated water savings are closer to the eTank calculated water savings in wet year. In reality, continuous simulation type water balance model results should be closer to the eTank calculated results in dry years. CSWBM calculated reliabilities were compared with the eTank calculated reliabilities in different climatic conditions. Again, it is found that CSWBM calculated reliabilities significantly vary with the eTank calculated reliabilities; for larger tank sizes CSWBM calculated reliabilities are much higher than the eTank calculated reliabilities even in wet year, which is not realistic. Presented comparisons reveals the fact that users should be cautious in using such computational tool(s) as some of these tools may produce erroneous results.
\end{abstract}

Keywords: Rainwater tank; daily water balance, water savings, climatic conditions 


\section{INTRODUCTION}

Recently, rainwater harvesting has drawn increased attention in many regions of the world as a sustainable and economic water source. Rainwater harvesting has maintained its importance as a water source for smallscale agriculture and as a primary water sources in remote locations in rural areas and islands. In the past few decades, rainwater harvesting has also become a popular supplemental (and generally non-potable) water source in urban and suburban areas. Water from the tanks can be used for non-potable purposes such as garden use, toilet flushing and washing clothes. This constitutes about $70 \%$ of the water consumed within a residential property. Therefore, this type of alternative source of water (eg. rainwater, recycled water) can contribute a great saving in town water supply.

For the rainwater tanks the largest economic consideration is the initial capital cost to construct and install the system. In most cases, the most important design decision is how much storage capacity to build. While the performance of rainwater harvesting systems depends on only a few system parameters, and the location's rainfall pattern, estimating required storage can be difficult and is often performed through a collection of rules-of-thumb, local experience, rough calculations, and judgment. The performance and sizing of rainwater harvesting systems have been explored in the past with a range of approaches including water balance and mass-curve analysis (Handia et al., 2002; Goel and Kumar, 2005), probabilistic methods (Guo and Baetz, 2007), economic optimization (Pandey, 1991; Liaw and Tsai, 2004; Matos et al., 2015), and detailed simulation and performance analysis (Fewkes, 2000; Ghisi et al., 2007). Many RWHS schemes were proposed by researchers in the past few decades (Aylward et al., 2006; Herrmann and Schmida, 2000; Imteaz et al., 2011b; Matos et al. 2014). In most cases, the most important design decision concerns the evaluation of the storage capacity according to the desired level of system performance.

Cheng and Liao (2009) explored regional zoning for rainwater harvesting systems in northern Taiwan using cluster analysis. Using the precipitation data from 72 stations, they derived a dimensional indicator to score rainwater harvesting system potential as function of regional rainfall characteristics and system's storage size. Hanson et al. (2009) provided a log-linear regressive relationship to calculate required storage capacity for a rainwater harvesting system which is generally applicable in the U.S. The equation is based on results of a behavioural model of a RWHS system and applied to daily time step records at 232 U.S. precipitation gauging stations. Although, the equation demonstrates good predictive performances at national scale, its application requires data elaboration to calculate climatic variables (daily rainfall statistics) to predict storage capacity. In order to generalise results, some authors have recently started exploring the variability of water saving at different spatial and temporal scales (Imteaz et al., 2012).

Among the mathematical modelling techniques used for rainwater tank analysis, daily water balance model is the most accurate. Outcomes of a continuous simulation type water balance model, CSWBM was presented by Eroksuz and Rahman (2010) on a daily time step. Another continuous simulation type water balance model, 'Raintank Analyser' is a spreadsheet based daily water balance tool developed by University of South Australia (UniSA, 2004). South Australian government used 'Raintank Analyser' to develop several design charts for the optimum sizing of rainwater tanks (DPLG, 2010). The tool produces expected average annual yields with respect to a range to tank sizes. However, users should be careful before implementing proposals from any such tool, as at times outcomes of different tools significantly vary with each other. Also, most of the studies including 'Raintank Analyser' who applied daily water balance modelling, used the model for continuous simulations of historical daily data for a long period (depending on data availability) and eventually making an average of cumulative historical savings (or other model variables). This sort of studies with long term rainfall data produces average outcomes, which many times do not happen, especially in the cities where inter-annual rainfall variability is very high. These sorts of studies present an impression to the users that the users are certain to save that much water every year. In reality this is not correct; rainfall in many cities show high degrees of inter-annual variability, especially with the impact of climate change this phenomenon is more significant.

Imteaz et al. (2011a) developed a daily water balance model/tool, eTank for the optimisation of rainwater tank size. Unlike other available tools, eTank produces rainwater tank outcomes for three distinct climatic conditions, i.e. dry, average and wet. Using the developed tool, climatic and spatial variabilities of potential rainwater tank outcomes were presented for different Australian cities, i.e. Melbourne (Imteaz et al., 2013) and Canberra (Imteaz et al., 2014). This paper presents comparison of potential water savings calculated by 
eTank with the 'Raintank Analyser' and other study using CSWBM for a coastal location in Sydney. Also, effects of climatic variability on potential water savings calculated by eTank were presented.

\section{METHODOLOGY}

eTank, a daily water balance model was developed considering daily rainfall, contributing catchment (roof) area, losses due to leakage, spillage and evaporation, storage (tank) volume and water uses. The daily runoff volume is calculated from daily rainfall amount by multiplying the rainfall amount with the contributing roof area and deducting the losses. Based on a guideline produced by Thomas and Martinson (2007), a 15\% deduction from the produced runoff was applied to account for losses (including leakage, spilling and evaporation). Generated runoff is then diverted to the available storage tank. Available storage capacity is compared with the accumulated daily runoff. If the accumulated runoff is higher than available storage volume, excess water (overflow) is deducted from the accumulated runoff. Then, the amount of water use(s) is deducted from the daily accumulated/stored runoff amount (if sufficient water is available in the storage). When sufficient water is not available in the storage, the model assumes that the remaining water demand is supplied from the town water supply. Thus, the model calculates daily stormwater use, daily water storage in the tank, daily overflow and daily town water use. In the earlier studies, eTank used a particular year for each of dry, average and wet years. However, a particular year might have an unusual rainfall pattern compared to usual pattern of occurrences (i.e. sporadic bursts and/or longer dry periods). As such this study suggests considering five years of data for each of the dry, average and wet conditions.

First, eTank calculated potential rainwater savings were compared with the 'Raintank Analyser' calculated potential water savings for similar input conditions. In the 'Raintank Analyser' in addition to providing daily in-house rainwater demand, there is a provision for monthly irrigation demands; however in the eTank there is no separate monthly provision for irrigation demand, i.e. eTank only requires total daily rainwater demand. As such for compatibility, in the 'Raintank Analyser' irrigation demand was taken as 'zero' and only in house water usages were used for both the tools. In the 'Raintank Analyser' initial loss and first flush loss amounts are provided in litres, whereas in eTank there is no such provision of providing these losses separately. Rather, all the losses (first flush, leakage, spillage) are amalgamated and provided as a percentage of total rainfall amounts. For compatibility, total loss amounts as a percentage of total rainfall for the entire period of rainfall data is calculated and converted into loss in $\mathrm{mm}$ by dividing number of rainy days and roof area, which was then used in the 'Raintank Analyser' as initial loss. Then, eTank was again compared with the calculations of potential rainwater savings and reliability presented by Eroksuz and Rahman (2010) for multi-unit buildings in Sydney using a continuous simulation type water balance model (CSWBM). For these calculations all the input data were considered same as used by Eroksuz and Rahman (2010).

\section{DATA}

Same non-potable water demand (162 1/person/day) was used as used by Eroksuz and Rahman (2010). 'Sydney Observatory Hill' rainfall station was selected in all three models. Daily rainfall data ranging from 1858 to 2005 was collected from Bureau of Meteorology website (http://reg.bom.gov.au/climate/data/). Ten different tank sizes $(10 \mathrm{~kL}, 20 \mathrm{~kL}, 30 \mathrm{~kL}, 40 \mathrm{~kL}, 50 \mathrm{~kL}, 60 \mathrm{~kL}, 70 \mathrm{~kL}, 80 \mathrm{~kL}, 90 \mathrm{~kL}$ and $100 \mathrm{~kL})$ for a multiunit residential building. To investigate the water savings potential from a rainwater tank, a detailed analysis was undertaken using the data presented in Eroksuz and Rahman (2010); site area $4000 \mathrm{~m}^{2}$, roof area $2000 \mathrm{~m}^{2}$, outdoor irrigation area $2000 \mathrm{~m}^{2}$ and 70 occupants (with 27 flats@2.6 persons per flat). For climatic variability analysis using eTank, through statistical analysis of total annual rainfall amounts, three separate years (2000, 1908 and 1998) were selected as dry year, median year and wet year. However, a particular climatic condition, a single year may exhibit an unusual pattern; as such for each climatic conditions 5 years' data were used. For the selection of 5 years' data, for each of the conditions four additional years were selected in a way that out of these four years, two years are having annual rainfalls immediately higher and the other two years are having annual rainfalls immediately lower than the rainfall amount of above selected years. Selected years and corresponding annual rainfall amounts are shown in Table 1.

Table 1. Selected annual rainfalls and corresponding years for the dry, average and wet years

\begin{tabular}{|l|l|l|l|l|l|l|l|l|l|l|l|l|l|l|l|l|}
\hline Climate & \multicolumn{10}{|l|}{ Dry } & \multicolumn{10}{l|}{ Average } & \multicolumn{1}{l|}{ Wet } \\
\hline Year & 1895 & 2005 & 2000 & 1982 & 1905 & 1884 & 1904 & 1908 & 1876 & 1945 & 1870 & 1934 & 1998 & 1949 & 1900 \\
\hline $\begin{array}{l}\text { Annual } \\
\text { Rainfall } \\
(\mathrm{mm})\end{array}$ & 812 & 816 & 821 & 838 & 888 & 1120 & 1138 & 1158 & 1160 & 1177 & 1630 & 1650 & 1667 & 1684 & 1691 \\
\hline
\end{tabular}




\section{RESULT / COMPARISON}

\subsection{Comparison of 'Raintank Analyser' and 'eTank'}

Figure 1 show the comparisons of expected annual water savings calculated by 'Raintank Analyser' and eTank for a roof area of $2000 \mathrm{~m}^{2}$ under different tank sizes ranging from $10 \mathrm{~kL}$ to $100 \mathrm{~kL}$. From the figure it is clear that under the same water usages conditions 'Raintank Analyser' calculated annual water savings closely match with the eTank calculated annual water savings in the average year. For almost all the tank sizes (except for smaller tanks) the calculated results are very close. Small variations are expected, as calculation methods are different in eTank and 'Raintank Analyser'; eTank calculates water savings for selected years (in this case 5 selected years for each of the dry, average and wet years), whereas 'Raintank Analyser' calculates water savings for many years (as per the extent of data) and then provides an average water savings calculated over a historical period (i.e. total accumulated water savings in many years divided by the number of years). Closeness of calculations proof accuracy of both the tools.

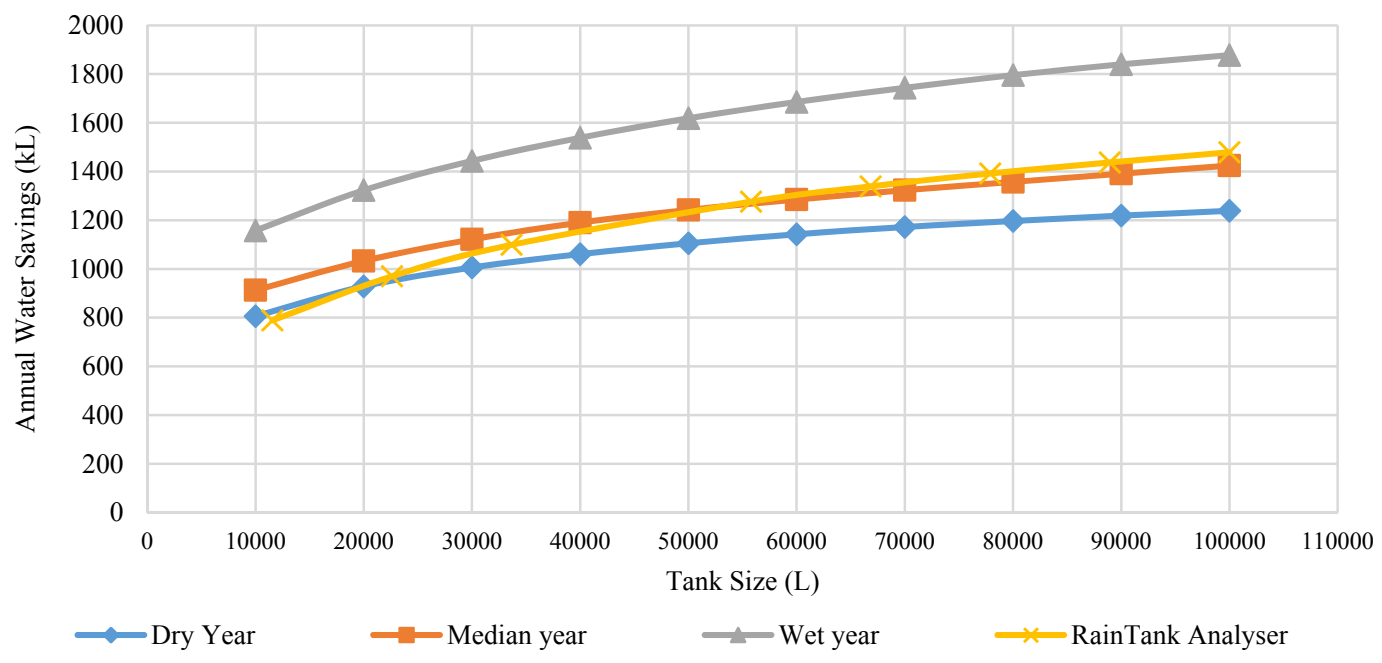

Figure 1. Comparison of expected annual water savings between 'Raintank Analyser' and eTank

\subsection{Comparison of 'CSWBM' and 'eTank'}

eTank simulated annual rainwater savings were again compared with the rainwater savings calculated by CSWBM. Both the models work with same concepts and logics, except that in CSWBM if the water level in the rainwater tank goes below a set minimum value, the tank is topped up with mains water to keep a minimum volume of water in the tank. Whereas, in the original eTank this minimum volume to trigger top-up was zero. To be compatible with the CSWBM results, eTank was modified to incorporate same top-up condition. Also, in regards to input data, total water demand including outdoor irrigation was considered. The initial losses, minimum level of water in the tank and other parameters are kept same as CSWBM. Expected annual water savings under different tank sizes ranging $10 \mathrm{~kL}$ to $100 \mathrm{~kL}$ for the same roof area of $2000 \mathrm{~m}^{2}$ was calculated by eTank and compared with CSWBM produced results. Figure 2 shows the comparison of results calculated by both the tools. From the figure it is clear that CSWBM calculated results significantly vary with the eTank calculated results; for the smaller size tanks (10kL-30kL) CSWBM underestimates water savings while for the large size tanks $(40 \mathrm{~kL}-100 \mathrm{~kL})$ it overestimates the water savings under the same conditions and input data. Ideally, CSWBM produced water savings should match with eTank produced water savings in median/average year, as it was found in the case of comparison with 'Raintank Analyser'. The slope of CSWBM produced water savings curve (in relation to tank size) is very stiff compared to eTank produced curve. It is to be noted that gradient of such curve produced by 'Raintank Analyser' is very similar to eTank produced curve. From the findings it is reasonable to conclude that CSWBM produced results are having some issues either in the programming codes or assumptions/uses of data. Also, it is clear from the figure that significant climatic variations are expected in regards to water savings. To clearly visualise the climatic variations, Figure 3 shows the expected water savings for four selected tank sizes $(20 \mathrm{~kL}, 50 \mathrm{~kL}, 70 \mathrm{~kL}$ 
\& $100 \mathrm{~kL}$ ) with a roof area of $2000 \mathrm{~m}^{2}$ under different climatic conditions as well as comparison with CSWBM. Another rainwater tank parameter to be considered is reliability, which is the measure of percentage of days in a year, the rainwater tank was able to supply intended demand. Both eTank and CSWBM calculate reliability. For further comparison, CSWBM calculated reliabilities were compared with eTank calculated reliabilities. Again, it is found that CSWBM calculated reliabilities are significantly different than the reliabilities calculated by eTank; ideally CSWBM calculated reliabilities should be similar to the eTank calculated reliabilities in median year. These discrepancies again support the earlier claim that there are some issues with the calculations of CSWBM.

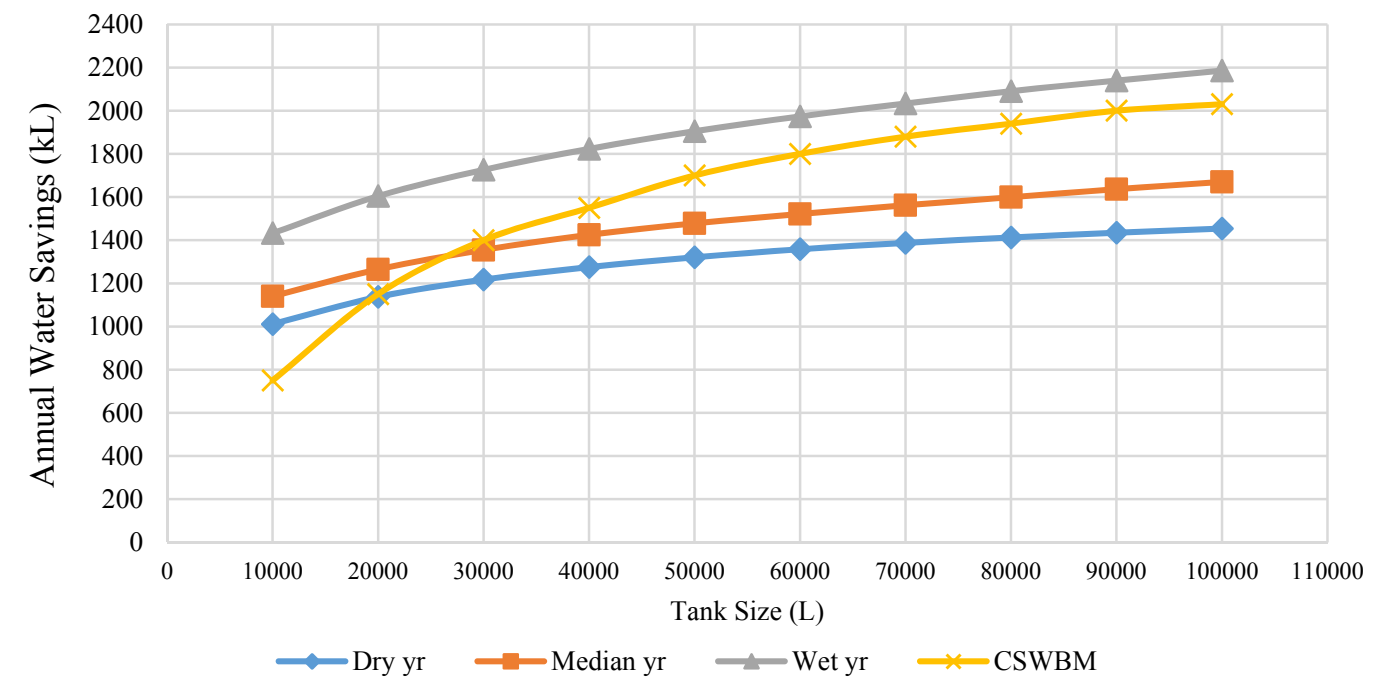

Figure 2. Comparison of expected total annual water savings between CSWBM and eTank

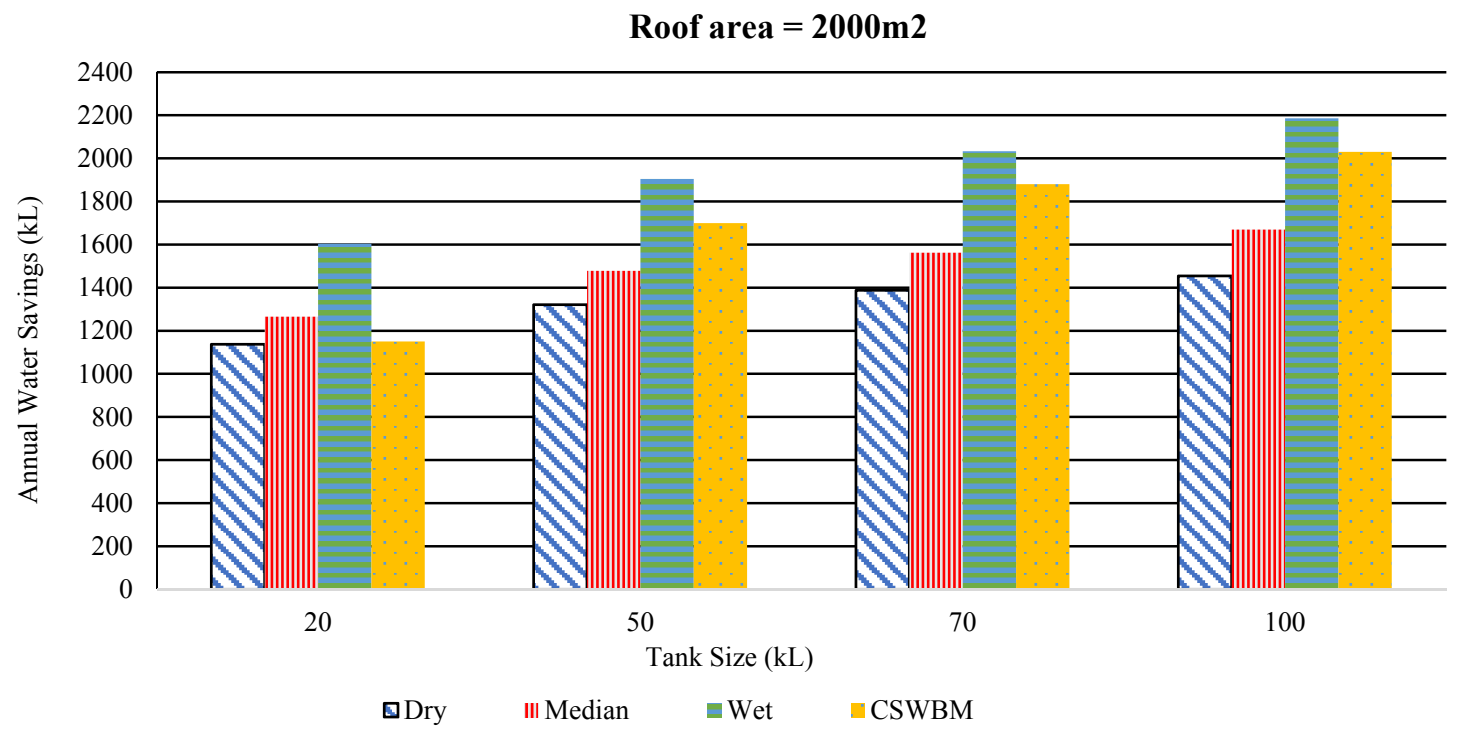

Figure 3. Comparison of expected annual water savings between CSWBM and eTank 


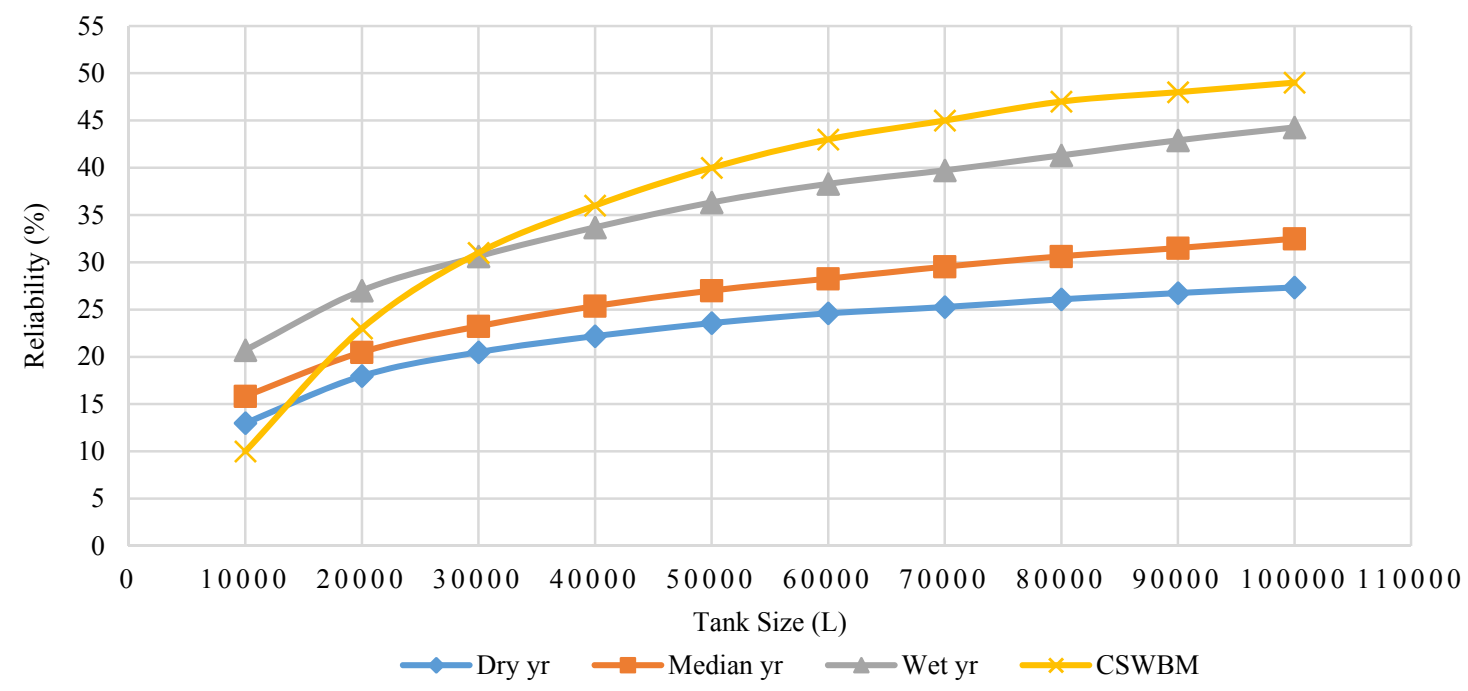

Figure 4. Comparison of expected reliability between CSWBM and eTank for $2000 \mathrm{~m}^{2}$ roof area

\section{CONCLUSION}

This paper investigated accuracy of three different tools (eTank, Raintank Analyser and CSWBM) used for rainwater tank design and optimisation. At first, eTank calculated expected water savings were compared with 'Raintank Analyser' calculated expected water savings under similar conditions. It is found that 'Raintank Analyser' calculated expected water savings closely match with eTank calculated expected water savings in average year, which is reasonable and supports accuracy of both the models. However, calculated water savings under a range of tank sizes are not exactly same for eTank and 'Raintank Analyser'. Nevertheless, it was not expected as calculation methods are different in eTank and 'Raintank Analyser'; eTank calculates water savings for selected years (dry, average and wet years), whereas 'Raintank Analyser' calculates water savings for many years and then provides an average of calculated water savings in many years. eTank calculated results were again compared with another set of published results using CSWBM. It is found that eTank calculated results significantly vary with the CSWBM calculated results both in regards to water savings and reliability. Gradient of annual water savings verses tank size curves for the CSWBM are very stiff; whereas gradients of similar curves by eTank and Raintank Analyser are mild. Also, annual water savings verses tank size curves for both the eTank and Raintank Analyser follow same pattern. As such, it can be concluded that CSWBM has got some issues either in coding of logical sequences or use/operation of data. Also, it is recommended that the users should be careful before implementing outcomes from any such tool. The paper also presented the climatic variabilities of rainwater tank outcomes for Sydney. In regards to climatic variability, it is found that for the studied scenario with a $100 \mathrm{~kL}$ water tank the wet year savings can be up to $2200 \mathrm{~kL}$, whereas dry year savings will be only $1450 \mathrm{~kL}$. Under same conditions for a small tank $(20 \mathrm{~kL})$ the wet year savings can be up to $1600 \mathrm{~kL}$, whereas dry year savings will be only $1137 \mathrm{~kL}$. In regards to reliability, it is found that effects of climatic variability are also significant. Also, it is found that $100 \%$ reliability is not achievable even with a very large tank $(100 \mathrm{~kL})$. It is recommended that a detailed cost analysis including payback period analysis to be performed for different scenario.

\section{REFERENCES}

Aylward, P.G., Casali, J.A., Porter, B.D. and Perjins, R.G. (2006) Grey water reclamation system and method for providing and operating same. U.S. Patent No. 7121292.

Cheng, C. and Liao, M. (2009) Regional rainfall level zoning for rainwater harvesting systems in northern Taiwan. Resources, Conservation and Recycling, 53, 421-428.

DPLG (2010) Water Sensitive Urban Design - Greater Adelaide Region Technical Manual, Department of Planning and Local Government, South Australian Government, ISBN 978-1-876702-99-1. 
Eroksuz, E. and Rahman, A. (2010) Rainwater tanks in multi-unit buildings: a case study for three Australian cities. Resources, Conservation and Recycling, Vol. 54, No. 12, 1449-1452.

Fewkes A (2000) Modelling the performance of rainwater collection systems: towards a generalized approach. Urban water, 1, 323-333.

Ghisi, E., Bressan, D.L. and Martini, M. (2007) Rainwater tank capacity and potential for potable water savings by using rainwater in the residential sector of southeastern Brazil. Building and Environment, Vol. 42, No. 4, 1654-1666.

Goel, A.K. and R. Kumar (2005). Economic analysis of water harvesting in a mountainous watershed in India. Agricultural Water Management, 71, 257 - 266.

Guo Y, Baetz BW (2007). Sizing of rainwater storage units for green building applications. Journal of Hydraulic Engineering 12(2), 197-205

Handia, L., J.M. Tembo, and C. Mwiindwa (2002). Potential of rainwater harvesting in urban Zambia. Proceedings of the 3rd WaterNet/Warsfa Symposium on Water Demand Management for Sustainable Development' Dar Es Salaam, Tanzania. 30 - 31 October, 2002.

Hanson, L., Vogel, R., Kirshen, P., and Shanahan, P. (2009) Generalized Storage-Reliability-Yield Equations for Rainwater Harvesting Systems, ASCE World Environmental and Water Resources Congress, Missouri, USA.

Herrmann, T. and Schmida, U. (2000) Rainwater utilization in Germany: Efficiency, dimensioning, hydraulic and environmental aspects. Urban Water, 1(4), 307-316.

Imteaz, M.A., Ahsan, A., Naser, J. and Rahman, A. (2011a). Reliability analysis of rainwater tanks in Melbourne using daily water balance model. Resources, Conservation \& Recycling, 56, No. 1, 80-86.

Imteaz, M.A., Ahsan, A. and Shanableh, A. (2013) Reliability analysis of rainwater tanks using daily water balance model: variations within a large city. Resources, Conservation \& Recycling, 77, 37-43.

Imteaz, M.A., Matos, C. and Shanableh, A. (2014) Impacts of climatic variability on rainwater tank outcomes for an inland city, Canberra. International Journal of Hydrology Science and Technology, 4 (3), 177-191.

Imteaz, M.A., Rahman, A. and Ahsan, A. (2012). Reliability analysis of rainwater tanks: a comparison between South-East and Central Melbourne. Resources, Conservation \& Recycling, 66, 1-7.

Imteaz, M.A., Shanableh, A., Rahman, A. and Ahsan, A. (2011b) Optimisation of Rainwater Tank Design for Large Roofs: A Case Study in Melbourne, Australia. Resources, Conservation \& Recycling, 55 (11), 10221029.

Matos, C., Santos, C., Bentes, I. and Imteaz, M.A. and Pereira, S. (2015) Economic analysis of a rainwater harvesting system in a commercial building, Water Resources Management, 29 (11), 3971-3986.

Matos, C., Santos, C., Pereira, S., Bentes, I. and Imteaz, M.A. (2014) Rainwater storage tank sizing: case study of a commercial building, International Journal of Sustainable Built Environment, Vol. 2, 109-118.

Liaw, C.H. and Y.-L. Tsai (2004). Optimum storage volume of rooftop rainwater harvesting systems for domestic use. Journal of the American Water Resources Association, 40(4), 901 - 912.

Pandey, S. (1991). The economics of water harvesting and supplementary irrigation in the semi-arid tropics of India. Agricultural Systems, 36, 207 - 220.

Thomas, T.H. and Martinson, D.B. (2007) Roofwater harvesting: a handbook for practitioners, IRC Publisher, Delft, The Netherlands, ISSN 9789066870574.

UniSA (2004) Rain Tank Analyser, http://www.unisa.edu.au/water/research/uwrg/raintankSoftware.asp, accessed on 23 July, 2014. 